\title{
THE MISSING STUDY \\ A characterization of peer education practice
}

\author{
Mara Fernandes da Silva \\ Centro de Estudos de Comunicação e Sociedade da Universidade do Minho (CECS-UM), Portugal
}

\section{Alice Delerue Matos}

Instituto de Ciências Sociais (ICS-UM) e Centro de Estudos de Comunicação e Sociedade da Universidade do Minho (CECS-UM), Portugal

\section{Susana Henriques}

Iscte - Instituto Universitário de Lisboa, Centro de Investigação e Estudos de Sociologia (CIES-Iscte); Universidade Aberta (UAb), Portugal

\begin{abstract}
Peer education interventions have grown significantly in recent decades, but sociological studies on the subject are limited. To respond to this need, we carried out an exhaustive inventory and characterization of 67 peer education projects developed in Portugal. The information given by the project managers was processed using a content analysis technique. This practice is growing, benefiting from public and private promotion. Although it has demonstrated some efficacy, further improvements can be made. The characterization undertaken allowed us to build a typology that summarizes this practice and that can be useful for researchers and practitioners in a context of globalization of risks and increased social intervention and reflexivity.
\end{abstract}

Keywords: peer education, characterization, Portugal.

O estudo em falta: uma caraterização da educação pelos pares

Resumo As intervenções de educação pelos pares cresceram bastante nas últimas décadas, mas são reduzidos os estudos sociológicos sob o tema. Para colmatar esta lacuna, realizámos um levantamento exaustivo e uma caraterização de 67 projetos de educação pelos pares em Portugal. A informação fornecida pelos seus responsáveis foi tratada através de uma técnica de análise de conteúdo. Esta prática tem crescido através de promoção pública e privada e apesar de ter demonstrado alguma eficácia, há aspetos que podem ser melhorados. A caraterização efetuada permitiu-nos construir uma tipologia que sumariza esta prática e que pode ser útil para investigadores e técnicos, num contexto de globalização dos riscos e de aumento da reflexividade e intervenção social.

Palavras-chave: educação pelos pares, caraterização, Portugal.

L'étude manquante: une caractérisation de la pratique de l'éducation par les pairs

Résumé Les interventions d'éducation par les pairs ont augmenté fortement au cours des dernières décennies, mais les études sociologiques sur le sujet sont limitées. Pour répondre à ce besoin, nous avons procédé à un inventaire exhaustif et à la caractérisation de 67 projets d'éducation par les pairs au Portugal. Les informations fournies par ses responsables ont été traitées avec une technique d'analyse de contenu. Cette pratique a augmenté avec le soutien public et privé, a démontré une certaine efficacité, mais des améliorations sont suggérées. La caractérisation effectuée a permis de construire une typologie sommaire de la pratique, utile pour les chercheurs et les techniciens, dans un contexte de mondialisation des risques et de l'augmentation de la réflexivité et d'interventions sociales.

Mots-clés: éducation par les pairs, caractérisation, Portugal.

Un estudio necessário: la caracterización de la práctica educativa entre iguales

Resumen Las intervenciones de educación entre pares crecieron bastante en las últimas décadas, pero los estudios sociológicos sobre el tema son limitados. Para responder a esta necesidad, se realizó un inventario 
exhaustivo y caracterización de 67 proyectos de educación entre pares en Portugal. La información cedida por sus responsables fue tratada a través de una técnica de análisis de contenido. Esta práctica ha crecido a través de la promoción pública y privada. A pesar de haber demostrado alguna eficacia, hay aspectos que pueden ser mejorados. La caracterización efectuada nos ha permitido construir una tipología que resume esta práctica y que puede ser útil para investigadores y técnicos, en un contexto de globalización de riesgos y mayor reflexividad e intervención social.

Palabras-clave: educación entre pares, caracterización, Portugal.

\section{Peer education's appeal for non-formal education and social intervention}

Non-formal education has expanded since the second half of the twentieth century (La Belle, 1982), in a context of increasing criticism of formal education and school institutions (Bernstein, 1996; Bourdieu and Passeron, 1999; Freire, 1975). This problematization and the social needs of an increasingly globalized and multicultural world have fostered its development. In this context, peer education has been an attractive tool for addressing emerging concerns such as the problematic use of drugs or the HIV/AIDS issues (Miller and MacGilchrist, 1996), whose stigmatization has hindered open debate and recognition in formal socio-educational contexts.

Peer education has been described as an approach that uses members from a given group who have been trained (or will be trained) to intervene with the remaining members of the same group, in order to achieve desirable changes (Shiner, 1999; Svenson, 2001; Turner and Sheperd, 1999). To this effect, peer education interventions have made it possible to access hard-to-reach groups and phenomena (McDonald et al., 2003) and have recorded significant growth over recent decades (Bagnall et al., 2015; Turner and Sheperd, 1999).

The main advantages associated with peer education concern processes of identification, influence and social learning among peers (Bandura, 1977; McDonald et al., 2003); greater participation and empowerment of participants (Campbell, 2005; Turner and Sheperd, 1999); and economic advantages, since it may involve lower costs and resources than traditional formal education (Parkin and McKeganey, 2000). On the other hand, criticisms of peer education include the lack of a robust theoretical-conceptual basis (Shiner, 1999); and the lack of a better understanding of the factors that contribute to the success of interventions (Parkin and McKeganey, 2000; Silva and Matos, 2014).

From a sociological perspective it is also important to note that peer education can be used as a form of social control. This may occur when individuals in a specific group are trained to foster the diffusion of dominant values and behaviours into deviant groups (Becker, 1973). This is most likely to occur in a priori planned interventions by members outside the group and without their participation. This strategy can also be quite appealing in a context of school divestment and 
public renouncement of educational functions (Ferreira, 2006). However, peer education can also be very useful as a non-formal education and social intervention strategy for social actors who want to intervene and change their communities (Campbell and MacPhail, 2002). It allows us to address some of the challenges of contemporaneity, such as fluctuating and geographically circumscribed social problems, new risks (Beck, 1992) that drive social action, innovation and the mobilization of knowledge (Beck, Giddens and Lash, 2000; Giddens, 2002). It is accessible to different groups and can be developed with fewer resources than formal education.

However, in order to gain a better understanding of peer education, it is necessary to begin by roughly characterizing its practice, without any a priori theoretical assumptions, given that its expressiveness and form is still largely unknown. This is the main objective of this paper - to show its main features so that we can thereby begin to problematize and deepen the sociological knowledge of this social intervention strategy. We will try to understand the actors, organizations, contexts, operations and results involved in Portugal's peer education practice.

While trying to maintain a very objective and descriptive focus on this initial characterization, we focus exclusively on some theoretical and analytical contributions based on the ideas of social action (Touraine, 1996), risk society (Beck, 1992) and social reflexivity (Giddens, 2002). These ideas help us achieve a better understanding of how growing awareness of existing and new risks that stem from globalization and greater social reflexivity prompt social intervention, socio-community dynamism and the use of peer education.

Regarding the scientific literature on peer education, there are only a few studies of a theoretical-critical nature and, above all, many studies that aim to evaluate specific project results. We can also find some systematic reviews that have contributed to recognising the potential of peer education. However, the vast majority of available studies do not characterize this practice in detail. In our review of the scientific literature, we only found four studies that included some type of characterization of peer education practice.

The first of these studies is by I. Brito and F. Mendes (2012). It characterized 12 Portuguese peer education projects in the field of health promotion, and essentially described the target groups, themes addressed, and the results obtained. The study stressed the difficulties in collecting this information, and in particular the results. It also stressed that the target groups were mainly formed by young people, and then by adults, and that the themes addressed were consumption of psychoactive substances, sexual health and risk behaviour in general, as well as community integration. Although working with scarce resources and little institutional support, the projects presented positive results. The second study, by S. Parkin and N. McKeganey (2000), included the characterization of 12 peer education projects in Scotland, in the field of young people's consumption of psychoactive substances, mainly in terms of location, aims, services, and financing. These projects were developed in rural or urban areas, in formal or informal contexts, and with varied funding, from private and public sources. The study highlighted the fact that despite the increase in the number of peer education projects, several weaknesses 
remained in terms of evaluation of the impacts in both groups involved (peer educators and the target audience - there are more difficulties in assessing the target group); the clarification of the objectives (to intervene at the level of knowledge or behaviour); and evaluation of its efficacy. The third study, by M. Shiner (1999), included the characterisation of five peer education projects in England, in the field of young people's consumption of psychoactive substances, and focused on aspects such as the concept of peer education; objectives and methods; the nature of peer involvement; empowerment of participants; support provided; skills development and incentives granted. The author emphasized that the peer education concept is shrouded in ambiguity and covers a wide range of interventions, objectives and methodologies. He also mentioned that projects developed in a community context, compared with those developed in a school context, delivered greater empowerment for the young people involved, and that support and incentives granted to participants were important in order to achieve positive results. Finally, the fourth study, by G. Svenson (2001), identified 24 peer education projects in 11 European countries, working in the field of human immunodeficiency virus (HIV). The author used the information obtained to provide technical indications for the development of similar projects.

These four studies did not present an exhaustive characterization of the peer education practice, which we consider to be an important requirement, in view of its increasing use (Brito and Mendes, 2012; Parkin and McKeganey, 2000; Turner and Sheperd, 1999) and the lack of such research in the scientific literature. There are also few sociological perspectives and studies into this topic. We therefore aim in this work to further knowledge about the characteristics of peer education practices, in particular in terms of their expressiveness, specificities, processes and actors involved in its use.

\section{Methods}

We used a qualitative methodological design for this research, with two distinct stages. The first stage consisted of a profound inventorying and mapping of peer education projects or subprojects developed in Portugal, and the second stage consisted in their characterization. The selection criteria considered the use of explicit/formal peer education, and the finish date of the projects, those that ended before 2012 were not selected. Since we had no specific database, we had to be creative. Aware that different types of public or private organizations, have implemented these projects - including schools, health institutions or non-governmental organizations (NGOs) - we chose to perform the inventory across four procedures: (a) we began by contacting and characterising projects that we were already aware of, and asked for other project referrals, using a logic of snowball sampling; (b) we contacted the Social Networks (database at https://appls.portalautarquico.pt, consulted on 26/04/2013), which are municipal working groups that encompass representatives of public and private organizations working in the fields of social work, health, education, and act in the municipal territories (they do or know the projects developed); 
(c) we contacted some key agencies involved in promotion of these projects (for example, the Ministry of Education, and the educational establishments database (at http://www.dgeste.mec.pt/index.php/escolas/pesquisa-de-escolas, consulted on 26/04/2013); and (d) we conducted a Web search as an auxiliary tool, to try to find any project that has escaped the previous scrutiny (with the descriptors: project / intervention of peer education). However, this procedure played a secondary role, and most projects were tracked by the first three procedures described above.

After verification of the references in the initial database, we ended up with a final group of 88 projects which used peer education methodology. Then, using a questionnaire form, we interviewed, between 2013 and 2015, in person, or in writing, the 67 projects managers that had agreed to participate in the study. The information of their answers was analysed and processed using a content analysis technique, based on thematic categories that were defined a priori, plus some analytical categories that emerged a posteriori, after the data analysis (Silva and Pinto, 1989). We used the MAXQDA programme to organise and manage the information. The results were validated by two researchers and discussed with other scientists. In particular, the two researchers agreed with the analytic dimensions [(a) promoters; (b) projects; (c) actors/groups involved; and (d) results] and indicators [(a) type of promoters, financing; (b) intervention field, partners, themes, methodologies, goals, training and implementation contexts, resources; (c) peer educators and target groups; (d) results achieved] introduced in the questionnaire form, that were based on the literature review and previous exploration of the field/several peer education projects. These supervisors also validated the analytic categories that emerged from processing the data in the MAXQDA programme [(a) public or private organisation or funding; (b) social or health area of intervention, different objectives and themes, volunteer or hired peers, formal and informal contexts, professionals fields; (c) age groups, socio-economic status; (d) results related with knowledge, skills and behaviour]. In this manner, for content analysis we conducted a formal discourse analysis, with the objective of reducing the information, describing it and grouping it into thematic categories that help us characterize the phenomenon. More information about the questionnaire form and the content analysis process may be requested.

Below, we present the main results of this research across the thematic categories, pointing out the number of cases or number of observations in each category. These are listed in descending order of case frequency (we sometimes omitted the less significant categories). This work is part of a larger research project into peer education and its impact on young people's consumption of psychoactive substances, which complies with the Ethical Conduct Code of the University of Minho. 


\title{
Results of the characterization of peer education projects
}

\author{
Private and public promoters with main public funding and different human
} resources

The 67 Portuguese peer education projects characterized have been promoted by either private or public entities. There was a slightly higher number of private entities $(\mathrm{n}=37)$ - such as civil society associations (for example, NGOs). The next biggest group was educational establishments $(n=16)$, public health institutions $(n=$ $8)$, and other public entities, such as municipalities $(n=6)$. In general, the project promoters benefit from partnerships with other similar actors, especially from the public sector, including less predictable partners - such as the police force or private companies. The majority of the projects have more than one partnership, an inter-institutional work that often results from the forms (and requirements) of external financing and the necessity for promoters to collaborate with other intervention actors. Also within peer education we have found major expression of networking and cooperation, which characterizes the contemporary (Giddens, 2002). Third sector organizations, which have boomed since 1980, seem to have seized the field of non-formal education (Fernandes and Garcia, 2019) as well as of peer education.

Most of the projects $(n=57)$ received public funding, mainly from the central and regional administration (especially from the Ministry of Health and Ministry of Education). Some of the projects also received funds from the European Union (such as the European Social Fund); and support from local public bodies, such as municipalities. Several projects $(n=38)$ also received private funding from their promoters or partners, usually as a complement to public funding, which is more significant overall. Finally, it should be noted that some projects $(n=9)$ did not receive any specific funding. We didn't aim to answer persistent questions about whether or not peer education interventions are more cost effective than other traditional interventions (Bagnall et al., 2015; Tolli, 2012), because this would depend heavily on the projects' characteristics, but the results indicate that it is possible to develop peer education projects without funding. This makes this strategy useful for actors with fewer economic resources who are willing to intervene socially. Despite the marginality associated with non-formal education, resulting from the legitimacy and validation that traditional education has achieved (Fernandes and Garcia, 2019; La Belle, 1982), the results show that peer education, directly or indirectly, has received public investment. This funding, which is not comparable to that for traditional education, cannot be neglected in the promotion of peer education. On the other hand, state funding of non-formal education conducted by third sector organizations has been linked to neoliberal socio-economic policies, which use private actors to develop functions that some commentators consider should be a public responsibility (educational and social intervention functions) (Fernandes and Garcia, 2019).

The majority of project managers are from the field of psychology $(n=21)$, followed by teachers $(n=16)$, especially higher education professors. There is a 
slightly lower number of social work specialists $(\mathrm{n}=11)$ and health specialists, such as nurses or physicians $(\mathrm{n}=6)$, among other professions. The vast majority of project managers have a high level of academic qualifications. Mobilization of these different expert fields enhances confidence in peer education (Giddens, 2002). In terms of the other human resources that complement these teams, almost half of the projects $(n=32)$ include volunteers, especially young people, mostly students, and also some professionals, such as teachers or psycho-social technicians, who worked on a pro-bono basis, usually part-time (approximately 340 volunteer students and approximately 140 volunteer professionals were indicated). It seems to us that the indicator on voluntary work may have been under-reported in some cases, but we can nonetheless perceive that most of the human resources assigned to these projects are volunteers. The great majority of projects $(n=60)$ declared that they also have employees, whose professional categories are similar to those of the project managers (psychologists, teachers, social workers, etc.). There were approximately 270 professionals indicated, even though a significant part also works part-time. It is interesting to note that nine of the 67 characterized projects stated that their teams hired peer educators, such as psycho-social technicians, monitors or others, given the lack of legal framework for this activity. This denotes the importance of these actors in certain community organizations, with the aim of reaching certain groups (e.g. "drug" users) (Bagnall et al., 2015; Parkin and McKeganey, 2000; Turner and Sheperd, 1999). So, should the profession of peer educators be created? This is an option to considered since overuse of volunteers can contribute to the problem of precarious employment.

\section{Few years duration, within health/social areas of intervention and themes}

Most of the Portuguese peer education projects in which we conducted interviews began after 2000. The duration of most of the 67 peer education projects was 1-2 years $(n=25)$. This period seems to be the most common, followed by the projects lasting between 6-8 years $(n=13)$, and between $3-5$ years $(n=11)$, wherein the others were of varied duration. It should be noted that the shortest project was conducted in a few days, while the longest project was developed systematically for almost 30 years, since the 1980s. This does not mean an uninterrupted duration of peer education interventions, since such interventions tend to be developed on a cyclical basis, generally for periods lasting a few months, or over an academic year, in the case of actions targeting students. Is this sufficient time to resolve the identified problems? In a context of acceleration, interventions also tend to be rapid and non-formal education and peer education enable greater flexibility and malleability, which is viewed positively within the current social context of globalization.

The projects operate in two main fields of intervention: above all the health field $(n=39)$ and the socio-community context $(n=28)$. In the first field there are interventions addressed to the problem of consumption of psychoactive substances, followed by prevention of risk behaviour in general, and finally, the promotion of health in the context of other specific problems, such as sexual health and sexually transmitted infections (STI). In the second field there are interventions that aim to 
promote activism and social change, as well as those working in the context of social support, that aim to promote, for example, the inclusion of minorities. There are also interventions that promote school learning, and those that seek development of personal, social or professional skills.

The issues addressed demonstrate that the power of social action is an active and mobilizing force to generate answers to current problems facing Portuguese society. Peer education is being used to respond to contemporary challenges, such as health risks or integration difficulties in the context of migration.

While school education is overwhelmed by the traditional syllabus, non-formal education seems to be one of the most viable responses to social education goals. However, and while most of the characterized peer education interventions target social "problems," we also find projects that foster development of professional skills among peers. Although at a smaller scale, peer education is also used to work on issues that are less socially "problematic". However, regarding the school content, there is no doubt that formal education is still the privileged option (cf. La Belle, 1982), wherein non-formal education or strategies such as peer education playing mostly a complementary role.

\section{Target groups primarily address young people}

Peer education has been mainly directed at groups of young people (Brito and Mendes, 2012; Parkin and McKeganey, 2000; Silva and Matos, 2014), given the importance and influence of peers in this stage of life (Bandura, 1977; Tajfel and Turner, 1986). Interventions with young people follow a prevention and awareness line for the problems addressed. As expected, two thirds of the projects reported that young people were their target groups. They were mainly secondary school students, followed by pre-secondary school pupils and then by higher education students. Many peer educators appear to have been chosen from the areas of health studies, followed by psychology and the social sciences. This seems to be consistent with the areas of intervention addressed and helps increase trust in the expert systems (Giddens, 2002) associated with these interventions.

However, peer education strategies are also being extended to other groups, and approximately one-third of the projects seek to intervene with adults. These correspond mainly to discriminated minorities, but not only, since we also found some projects that intend to promote health or develop professional skills with adults without social inclusion problems. Residually, we also found some projects that work with children for prevention or improvement of learning, and the elderly, especially in order to promote life quality or social inclusion. Once again, these results tend to dissociate the use of peer education or non-formal education from working with disempowered or stigmatized groups (Fernandes and Garcia, 2019; La Belle, 1982) and highlight their versatility.

Concerning the role of peer educators, only two projects stated that this role is given to senior citizens and in only one project was this role performed by children. However, when we look at the target peer groups of the 67 projects characterized, these include a much higher number of senior citizens and children. We know that 
age group has been one of the most used and relevant criteria, but not the only, in defining "peer" identity (McDonald et al., 2003). But in these projects other criteria must necessarily have been used for this definition (for example other group and socio-cultural characteristics), to avoid undermining social identification mechanisms, that are important in peer education processes (McDonald et al., 2003; Shiner, 1999).

There is a rough balance between males and females involved in peer education projects, although there seems to be a slightly higher presence of females in the peer educator groups and a slightly higher presence of males in the target audiences. It appears that women are more likely to volunteer for such actions, such as Strange, Forrest and Oakley (2002a) have suggested. In socio-economic terms, both in peer educators and their target audiences, there is a predominance of heterogeneous situations, following groups that present a precarious socio-economic situation and, finally, those who have a socio-economic favoured situation. However, focusing solely on target peer groups, in general these records heterogeneous or precarious, but no favoured, situations, which suggests that individuals who volunteer, or that are recruited, as peer educators, have a better socio-economic situation than the target audience. This is something that has also been observed previously (Strange, Forrest and Oakley, 2002a) and that we recommend should be analysed in further detail. This can foster some form of peer educator compensation when involving low-income participants. Again, marked differences in socio-economic status can undermine the identification processes that are important for peer education (McDonald et al., 2003; Shiner 1999).

(Two-phase) methodologies, (mostly with) training and (in)formal implementation contexts

Most projects form a group of individual volunteers, who will subsequently intervene with the target audience, usually in a team, over a specific period of time. However, we also found a small set of projects that included one or more peer educators in their working teams, as paid professionals. In these projects, no initial training period was given due to the experience of these individuals.

The training that a large part of the participants must perform in an initial phase to become peer educators is primarily constituted by specific contexts and spaces that tend to be formal, i.e., wherein the roles and social positions are clearly demarcated $(n=61)$. Thus, a significant number of courses were performed in classrooms or other school spaces, followed by courses that were held in conference rooms or offices of other private entities, such as social institutions. Only a very small number of projects indicated that the courses occurred in contexts considered to be informal, such as outdoor spaces $(n=6)$.

However, this difference is attenuated in relation to the implementation contexts of peer education. Although the formal contexts described above continue to be expressive $(n=40)$, informal contexts are now more numerous $(n=27)$. Some projects use both contexts, e.g. festive contexts (nightlife, academic festivities) or everyday social and informal relations. If some form of participants' empowerment is sought, 
it is important to think about using more informal contexts, in which individuals feel less constrained by traditional power relationships (Campbell and MacPhail, 2002; Shiner, 1999; Strange, Forrest and Oakley, 2002b). In fact, more horizontal, democratic and interactive learning underpins the rationale of peer education (Shiner, 1999).

Objectives and results - skills, behaviour and knowledge, a need to improve evaluations

The projects characterized often had more than one goal. In this context, the objectives that were most mentioned relate to the acquisition or development of personal, social, educational or professional skills $(n=34)$; the promotion of health through adoption of less risky behaviour $(n=32)$; the increase of knowledge, in particular in the health field $(\mathrm{n}=28)$ and, finally, the promotion of social and community inclusion $(n=24)$ and the provision of socio-health support services $(n=$ 15). There were fewer references than might be expected $(n=6)$ to the promotion of participation and empowerment objectives, although these processes have often been associated with peer education (Campbell, 2005; Klein et al., 2014; Parkin and McKeganey, 2000; Turner and Sheperd, 1999). From a sociological perspective, attention must be paid to the people who sets goals and how they are pursued. As noted, peer education can be a tool for emancipation (Freire, 1975) or social control (Foucault, 2013), and therefore issues of power, ethics, and participation need to be addressed at an early stage in the planning.

It was not easy to collect data about the results of final evaluations of the peer education projects that we characterized. Some projects experienced some difficulties in providing such data, for example, due to weak evaluations or excessive attention to process indicators, since some of them just have collected process indicators. This could be related to evaluation failures and/or lack of resources for final evaluations. Often the bureaucratic and financing system is more demanding with the process indicators, which condition the transfer of financial tranches. However, the projects that presented their results indicated positive effects, such as increased knowledge about the themes developed $(n=26)$; acquisition and development of skills $(n=20)$; increased adherence to support services (social, health, etc.) $(n=10)$; the reduction and modification of risk behaviours $(n=9)$ and improved access to hard-to-reach groups or hidden phenomena $(n=9)$. Nevertheless, as noted above, the fact that projects demonstrate positive results or are effective does not mean that they respect cultural differences or ethical principles, or even the participation of those involved. This interpretation should therefore be made carefully from a sociological perspective.

Only about half of the projects that provided us with their results broke them down in function of the two main groups involved - the peer educators and the target audience, with slightly better results recorded for the peer educators group, predominantly in terms of increased knowledge and skills development, while in the target audience the results indicated increased adherence to support services. This is an important distinction that should be clarified in projects, and that has 
already been criticized (Parkin and McKeganey, 2000) because the target groups can be both peer educators and target audience, which is sometimes not specified by the projects. The first group may present better results by becoming more involved (they usually receive training), are closer to the project managers, and therefore more accessible for evaluation, but they may not be considered to be target groups by the projects (Winter, 2013). On the other hand, analysis of the target audience is often the main objective, but it may be more difficult to achieve and assess this group. Hence, the results of peer education projects should contain a qualitative assessment that analyses the objectives, intended changes and the outcomes observed in the different groups and participants.

Typology of the peer education projects: school and community; health and social integration; young people and adults; volunteer peers and hired peers

The characterization performed enabled us to build a summary and representative typology of Portuguese peer education practice. This corresponds, in descending order of frequency to:

1) health/learning/social inclusion promotion projects fully developed in a school context with young student volunteers;

2) health/social support/learning promotion projects developed with young or adult volunteers in a community context (e.g. civic associations; NGOs);

3) health/social inclusion promotion projects that recruit student volunteers in the school context, but whose intervention is developed in a community context (e.g. young recreational settings);

4) health/social support promotion projects, in general targeting adults, with peer employees, developed in a community context (e.g. civic associations; NGOs).

In short, peer education practice continues to be dominated by projects developed with young volunteers, in the school context, in the health promotion field (Brito and Mendes, 2012; Parkin and McKeganey, 2000; Shiner, 1999; Turner and Sheperd, 1999). However, we also found less expected projects that use peer education to develop professional skills among work colleagues, or disseminate community gardens and a healthier diet among adult groups. Some projects target less common groups - such as children or the elderly and some already hired peer educators, which suggests a growth and diversification of this practice.

\section{Strengths and limitations}

This study adopted an innovative methodology in terms of the inventory and mapping of Portuguese peer education projects, which enabled us to make an exhaustive and in-depth unprecedented characterization, even if it has not been possible to obtain the cooperation of all projects identified (67 in 88). Taking into account the 
literature review, we have been able to draw up the first-ever exhaustive classification of peer education projects covering aspects such as their human resources, duration, methodologies, training and implementation contexts. We believe we have obtained a fairly accurate overview of peer education practice in Portugal, and with the inclusion of the contributions of other publications, it has also been possible to obtain a European overview of the phenomenon, although exploratory and superficial. Either way, this research can be replicated and adapted to other countries by other researchers.

\section{Peer education is expanding and diversifying, but entrenched weaknesses remain}

The characterization of Portugal's peer education projects (and also the literature on the subject) has enabled us to find a practice that is more widespread than we expected in Portugal and confirmed that the use of this intervention strategy has increased over recent years. Both the private sector and the public sector have been using peer education, but private organizations are the main promotors of such projects, even though they tend to depend mostly on public funding. This suggests that peer education has been widely used in partnerships between the state and the social sector. Similar results were found by Parkin and McKegany (2000) in the United Kingdom. Volunteer work stands out and only a limited number of projects incorporate remunerated peer educators in their work teams. Peer education has been primarily used to work on health and social issues, mostly with groups of young people, but also with adults, and more recently, with groups of children or senior citizens. The peer educators present a socio-economic situation that is slightly better than their target audience, as well as a higher proportion of females, which should be reflected during planning of the projects, for example, to avoid neglecting group and social identification processes.

Use of peer education has gained more supporters and greater credibility due to its evaluation results, but this study demonstrates that some problems persist regarding the design, implementation and evaluation of projects, as has been previously stated by Parkin and McKeganey (2000). Although the projects characterized have presented positive results, it is necessary to improve the collection and dissemination of final evaluation indicators. A better clarification of the target groups and their respective results is still required (Brito and Mendes, 2012; Parkin and McKeganey, 2000). The growing recognition of this strategy of social intervention, its versatility and the possibility of being developed economically, suggests further expansion of this type of intervention and its use for an increasingly diversified range of problems or issues.

In short, from a sociological perspective, peer education is a very useful non-formal education strategy for social action on different issues, in particular those arising from the phenomena of globalization and current change. This strategy can encompass the socio-cultural collection of educational wealth and contributes to valorisation of different educational approaches (Fernandes and Garcia, 2019), since 
society is a "project" under development. However, it is necessary to reflect on important issues when planning interventions, such as control, power, participation and change issues related to the groups involved, in particular the managers and the target peers. One important aspect is how peer education is mobilized, operationalized or politicized. The principles of peer education encourage integration, emancipation, liberation, democratization, participation and empowerment, and therefore peer education training / actions should include these aspects. We recommend carrying out similar studies that will make it possible to further and extend knowledge about peer education in other countries, and perhaps even promote the establishment of international partnerships or networks in this field.

\section{Acknowledgements}

We are grateful to the 67 peer education projects that cooperated with this research.

\section{Funding}

This work was supported by the Portuguese Science and Technology Foundation (FCT) (PhD research grant SFRH/BD/78271/2011); the Portuguese National Strategic Reference Framework - Human Potential Operational Programme; co-financed by the European Social Found and by national funds from the Ministry of Science, Technology and Higher Education.

\section{Conflict of interest statement}

None declared.

\section{References}

Bagnall, A., J. South, C. Hulme, J. Woodall, K. Vinall-Collier, G. Raine, K. Kinsella, R. Dixey, L. Harris, and N. M. Wright (2015), "A systematic review of the effectiveness and cost-effectiveness of peer education and peer support in prisons", BMC Public Health, 15 (1), p. 290.

Bandura, Albert (1977), Social Learning Theory, Upper Saddle River, Prentice Hall. Beck, U. (1992), Risk Society. Towards a New Modernity, London, Sage.

Beck, U., A. Giddens, and S. Lash (2000), Modernização Reflexiva. Política, Tradição e Estética no Mundo Moderno, Oeiras, Celta Editora.

Becker, H. S. (1973), Outsiders. Studies in the Sociology of Deviance, New York, The Free Press.

Bernstein, B. (1996), A Estruturação do Discurso Pedagógico. Classes, Códigos e Controle, Petrópolis, Vozes. 
Bourdieu, P., and J. Passeron (1999), La Reproduction. Eléments pour Une Théorie du Système d'Enseignement, Paris, Les Editions de Minuit.

Brito. I., and F. Mendes (2012), "PEER: Avaliação de projetos de Educação pelos Pares", in I. Brito and F. Mendes (Coord.), PEER IV. Escola de Verão em Educação pelos Pares $\mathcal{E}$ Investigação Ação Participativa em Saúde, Coimbra, Edições Escola Superior de Enfermagem de Coimbra, pp. 47-56.

Calazans, G., L. Kiss, S. Capellini, D. Sequeira, and R. M. Vieira (2006), “Plantões jovens: acolhimento e cuidado por meio da educação entre pares para adolescentes e jovens nos Centros de Testagem e Aconselhamento - CTA", Saúde e Sociedade, 15 (1), pp. 22-36.

Campbell, S. (2005), “Using peer education projects to prevent HIV/AIDS in young people", Nursing Standard, 20 (10), pp. 50-55.

Campbell, C., and C. MacPhail, (2002), "Peer education, gender and the development of critical consciousness: participatory HIV prevention by South African youth", Social Science E Medicine, 55, pp. 331-345.

Fernandes, R. S., and V. A. Garcia (2019), “Educação não formal no contexto brasileiro e internacional: tensões que perpassam a formulação conceitual", Espaço Pedagógico, 26 (2), pp. 498-517.

Ferreira, R. (2006), “Sociologia da educação: uma análise de suas origens e desenvolvimento a partir de um enfoque da Sociologia do conhecimento", Revista Lusófona de Educação, 7, pp. 105-120.

Foucault, M. (2013), Vigiar e Punir. Nascimento da Prisão, Lisboa, Edições 70.

Freire, P. (1975), Pedagogia do Oprimido, Porto, Afrontamento.

Giddens, A. (2002), As Consequências da Modernidade, Oeiras, Celta Editora.

Klein, L., J. Ritchie, S. Nathan, and S. Wutzke (2014), “An explanatory model of peer education within a complex medicines information exchange setting", Social Science \& Medicine, 111, pp. 101-109.

La Belle, T. J. (1982), “Formal, nonformal and informal education: a holistic perspective on lifelong learning", International Review of Education, 28, pp. 159-175.

McDonald, J., A. Roche, M. Durbridge, and N. Skinner (2003), Peer Education. From Evidence to Practice, an Alcohol and Other Drugs Primer. Flinders University of South Australia, Adelaide, National Centre for Education and Training on Addiction (NCETA).

Miller, W., and L. MacGilchrist, (1996), "A model for peer-led work", Health Education, 2, pp. 24-29.

Parkin, S., and N. McKeganey, (2000), "The rise and rise of peer education approaches", Drugs - Education, Prevention \& Policy, 7 (3), pp. 293-310.

Silva, A. S., and J. M. Pinto (Coord.) (1989), Metodologia das Ciências Sociais, Porto, Afrontamento.

Silva, M., and A. Matos (2014), “Educação pelos pares, jovens e droga: análise da produção científica portuguesa", in P. Delgado, S. Barros, C. Serrão, et al. (Coord.), Pedagogia/Educação Social - Teorias E Práticas - Espaços de Investigação, Formação e Ação, Porto, Escola Superior de Educação do Porto, pp. 319-323.

Shiner, M. (1999), “Defining peer education”, Journal of Adolescence, 22, pp. 555-566. 
Strange, V., S. Forrest, and A. Oakley (2002a), "Peer-led sex education - characteristics of peer educators and their perceptions of the impact on them of participation in a peer education programme", Health Education Research, 17 (3), pp. 327-337.

Strange, V., S. Forrest, and A. Oakley (2002b), “What influences peer-led sex education in the classroom? A view from the peer educators", Health Education Research, 17 (3), pp. 339-349.

Svenson, G. (Coord.) (2001), European Guidelines for Youth AIDS Peer Education, Lund University, Department of Community Medicine.

Tajfel, H., and J. C. Turner (1986), "The social identity theory of inter-group behaviour", in S. Worchel and W. G. Austin (Coord.), Psychology of Intergroup Relations, Chicago, Nelson-Hall, pp. 33-47.

Touraine, A. (1996), O Retorno do Ator, Lisboa, Instituto Piaget.

Tolli, M. (2012), “Effectiveness of peer education interventions for HIV prevention, adolescent pregnancy prevention and sexual health promotion for young people: a systematic review of European studies", Health Education Research, 27 (5), pp. 904-913.

Turner, G., J. Sheperd (1999), "A method in search of a theory: peer education and health promotion", Health Education Research, 14 (2), pp. 235-247.

Winter, V. R. (2013), “Diffusion of innovations theory: a unifying framework for HIV peer education", American Journal of Sexuality Education, 8 (4), pp. 228-245.

Mara Fernandes da Silva. Researcher at Centro de Estudos de Comunicação e Sociedade da Universidade do Minho. E-mail: mara.silva.prof@gmail.com

Alice Delerue Matos. Assistant professor at Instituto de Ciências Sociais da Universidade do Minho. Researcher at Centro de Estudos de Comunicação e Sociedade. E-mail: adelerue@ics.uminho.pt

Susana Henriques. Assistant professor at Departamento de Educação e Ensino à Distância da Universidade Aberta. Researcher at Centro de Investigação e Estudos de Sociologia do Iscte - Instituto Universitário de Lisboa (CIES-Iscte).

E-mail: susana.henriques@uab.pt

Receção: 01 de novembro de 2019 Aprovação: 24 de março de 2020 
